\title{
Studies on Milk Production and Health Management for Livestock in Western Uttar Pradesh, India
}

\author{
Satyaveer Singh, Nazim Ali, Jagdeep Kumar*, Hitesh Singh and Harendra Singh Chauhan \\ Department of Animal Husbandry, College of Veterinary and Animal Sciences, Sardar \\ Vallabhbhai Patel University of Agriculture and Technology, Meerut-250110, (U.P.), India \\ *Corresponding author
}

\section{A B S T R A C T}

Studies of the 160 farmers were selected randomly from 16 villages of Meerut, Hapur, Bulandshahar and Gautambudhnagar districts i.e. 4 villages from each district. The average milk production was 9.38, 9.40, 9.39 and 9.52 litter/day/family in Meerut, Hapur, Bulandshahar and Gautambudhnagar districts. It was found that there was non-significant

Keywords

Livestock,

Disposal, Milk production, Health.

Article Info

Accepted:

29 June 2017

Available Online:

10 July 2017 $(\mathrm{P}<0.05)$ difference among the districts. Over all milk production was higher in the $\mathrm{C}_{5}$ category of farmers and lower in $\mathrm{C}_{1}$ category. There was significant difference among the $\mathrm{C}_{1}$ and other categories of farmers in respect to total milk production. Value of animal feed grade was also significantly higher in $\mathrm{C}_{5}(4.13 \mathrm{~kg} /$ day $)$ category of farmers over all other categories and it was followed by $\mathrm{C}_{4}(3.00 \mathrm{~kg} / \mathrm{day}) . \mathrm{C}_{1}$ category recorded lowest value of animal feed grade. Similarly difference among districts was statistically significant and Gautambudhnagar recorded maximum value of animal feed grade over other districts. Meerut tended to lowest value of animal feed grade. Significant difference was observed for vaccination in buffaloes by $C_{5}(0.11)$ over $C_{1}, C_{2}$ and $C_{3}$ and followed by $C_{4}(0.09)$ over $\mathrm{C}_{1}$ and $\mathrm{C}_{2}$. Difference between $\mathrm{C}_{1}$ and $\mathrm{C}_{2}, \mathrm{C}_{2}$ and $\mathrm{C}_{3}, \mathrm{C}_{1}$ and $\mathrm{C}_{3}, \mathrm{C}_{3}$ and $\mathrm{C}_{4}, \mathrm{C}_{4}$ and $\mathrm{C}_{5}$ was no significant. Among districts Bulandsahar (0.10) recorded maximum vaccination value which was significant higher over Gautambudhnagar. Other districts were at par with the each other. Overall breeding differ significant among farmer categories. $\mathrm{C}_{4}(2.22)$ recorded maximum and significantly higher breeding score in buffaloes over other famer categories. Among districts, Gautambudhnagar recorded maximum (1.99) breeding score which was significantly higher than Meerut (1.23) and Hapur (2.29).

\section{Introduction}

There is an increasing consensus that in the developing countries, growth in agriculture is more poverty-reducing than the growth in other economic sectors. In India, agriculture and allied activities, despite their falling shares in the gross domestic product, are central to livelihood of millions of rural people. Nearly $72 \%$ of India's population lives in rural areas, and $75 \%$ of it depends on agriculture and allied activities for livelihood.
In 2002-03, the small farm households ( $<2$ ha) comprised $60 \%$ of the rural households, controlled $76 \%$ cattle, $72 \%$ buffaloes, $80 \%$ small ruminants, $83 \%$ poultry and $90 \%$ pigs. Thus, faster growth in livestock sector has considerable potential to contribute to agricultural growth and thereby poverty reduction by Birthal and Taneja (2006). The National Agricultural Policy targets 4\% growth in agriculture sector over the next two 
decades and envisages an important role for the livestock sector in achieving it. The livestock industry success depends on health of the livestock, good health increases productivity and any compromise on health ground will shatter the hope of livestock sector. Total bovine population of Himachal Pradesh was 3.03 million, which was approximately $1 \%$ of India's bovine population (304.42 million). India is the highest milk producer in the world (121.85 million tons of milk, 2010-11) out of which bovine milk production was 117.253 million tons) by BAHS 2012. Uttar Pradesh (U.P.) is the highest populous state in India as well as the largest contributor to the national milk production (210.33 lakhs $\mathrm{mt}$ ) contributing around $18 \%$ of total milk production in the country. It has got the second highest cattle population (18883 thousand) and highest buffalo population (26119 thousand) and share of milk production by cattle and buffaloes is 47825 and 59201 thousand tonnes, respectively. Per capita availability of milk in the state is 289 grams BAHS, 2012.

Consumption of milk and milk products is expected to differ for different occupational groups due to differences in the habits and social customs. Average monthly per capita expenditure (MPCE) of Uttar Pradesh is about rupees 899 and rupees 1574 out of which per capita expenditure on food in rural and urban areas of Uttar Pradesh is about rupees 521 and rupees 728, respectively; and percentage share of food in consumer expenditure is about 57.9 percent and 46.3 percent, respectively NSSO, GOI, 2009-10.

\section{Materials and Methods}

\section{Selection of farmers}

Farmers were selected randomly from the selected villages. From a selected village five farmers were selected on the basis of size of land holdings, i.e. zero, up to 5, 5-10, 10-20 and above 20 acres. Land less farmers termed as $\mathrm{C} 1$, up to 5 acre $\mathrm{C} 2,5-10$ acre $\mathrm{C} 3,10-20$ acre $\mathrm{C} 4$ and above 20 acres C5 category of farmers.

\section{Statistical analysis}

Statistical analysis was done by Computer FRBD $5 \times 4 \times 4$, and was used to compare the differences between categories. The null hypothesis tested was the different categories of farmers within and between districts have same feeding status Bouler et al., 1996.

\section{Results and Discussion}

Milk production was significantly $(\mathrm{P}<0.05)$ difference between Gautambudhnagar and other districts. Cattle milk production was significantly difference among the category of farmers. $C_{5}$ category produced significantly higher milk by cattle (5.00 litter/day/family) while $\mathrm{C}_{1}$ produced lowest (1.70 litter/day/family). Among the districts Gautambudhnagar produced significantly higher milk as compared to Meerut and Hapur while at par with Bulandshahar. There were significant difference in milk production among the districts and categories were significantly difference among each other and buffalo milk production was higher in the $\mathrm{C}_{5}$ category (9.05 litter/day/family). Among districts maximum milk production (6.31litter/day/family) was found in Bulandshahar.It was found that there was non-significant difference among the districts. Over all milk production was higher in the $\mathrm{C}_{5}$ category of farmers and lower in $\mathrm{C}_{1}$ category. There was significant difference among the $\mathrm{C}_{1}$ and other categories of farmers in respect to total milk production (Table 1).

It was observed that milk consumption significant $(\mathrm{P}<0.05)$ difference among the districts viz. Meerut, hapur, Bulandshahar and 
Gautambudhnagar. Milk consumption was significantly lower in $\mathrm{C}_{1}$ category (1.85 litter/day) in comparison to other categories but $\mathrm{C}_{3}, \mathrm{C}_{4}$ were not significantly difference and $\mathrm{C}_{4}, \mathrm{C}_{5}$ were significantly difference from each other. Quantity of sold milk is also not significant differences among the Meerut, Hapur, Bulandshahar and Gautambudhnagar districts. Quantity of sold milk was significantly $(\mathrm{P}<0.05)$ higher in the $\mathrm{C}_{5}$ category (Table 1).

The value of animal health was higher in $\mathrm{C}_{5}$ category $(4.56 \mathrm{~kg} / \mathrm{day})$ of farmers followed by $\mathrm{C}_{1}$ and it was significantly $(\mathrm{P}<0.05)$ deference higher over $\mathrm{C}_{2}, \mathrm{C}_{3}$ and $\mathrm{C}_{4}$ categories of farmers. $C_{2}$ category recorded lowest value of animal health grade. Similarly difference among Hapur and Gautambudhnagar was statistically significant and Gautambudhnagar (3.99 $\mathrm{kg} /$ day) recorded maximum value of animal health grade.

Hapur tended to lowest value of animal health grade. Value of animal feed grade was also significant higher in $\mathrm{C}_{5}(4.13 \mathrm{~kg} /$ day $)$ category of farmers over all other categories and it was followed by $\mathrm{C}_{4}(3.00 \mathrm{~kg} /$ day $) . \mathrm{C}_{1}$ category recorded lowest value of animal feed grade. Similarly difference among districts was statistically significant and Gautambudhnagar recorded maximum value of animal feed grade over other districts. Meerut tended to lowest value of animal feed grade (Table 2).

Artificial insemination in buffaloes was significantly $(\mathrm{P}<0.05)$ differ among farmer categories. $\mathrm{C}_{5}(0.53)$ recorded maximum and significantly higher artificial insemination over $\mathrm{C}_{1}, \mathrm{C}_{2}$ and $\mathrm{C}_{3}$ categories. Among districts Gautambudhnagar was having maximum (0.42) and significantly higher artificial insemination over Hapur (0.26). Other districts were at par with the each other in this aspect. Vaccination of the buffaloes was observed Significant differ for by $\mathrm{C}_{5}$
(0.11) over $\mathrm{C}_{1}, \mathrm{C}_{2}$ and $\mathrm{C}_{3}$ and by $\mathrm{C}_{4}(0.09)$ over $\mathrm{C}_{1}$ and $\mathrm{C}_{2}$. Difference between $\mathrm{C}_{1}$ and $\mathrm{C}_{2}, \mathrm{C}_{2}$ and $\mathrm{C}_{3}, \mathrm{C}_{1}$ and $\mathrm{C}_{3}, \mathrm{C}_{3}$ and $\mathrm{C}_{4}, \mathrm{C}_{4}$ and $\mathrm{C}_{5}$ was no significant. Among districts Bulandsahar (0.10) recorded maximum vaccination value which was significantly superior over Gautambudhnagar. Other districts were at par with the each other.

It was recorded maximum for $\mathrm{C}_{1}$ category (3.00) of the farmers which was significantly higher over the other farmer categories. Gautambudhnagar (0.76), Bulandsahar (0.73) and Hapur (0.67) recorded significantly higher shelter management over Meerut (0.52) district (Table 3).

Artificial insemination in cattle was significant $(\mathrm{P}<0.05)$ difference among farmer categories. $\mathrm{C}_{5}(0.39)$ recorded maximum and significantly higher artificial insemination over $\mathrm{C}_{1}, \mathrm{C}_{2}$ and $\mathrm{C}_{3}$ categories. Among districts the difference was found to be nonsignificant in this aspect. However, Gautambudhnagar was having maximum (0.29) artificial insemination followed by Bulandsahar (0.24).Vaccination of the cattle was observed Significant difference for among different categories of the farmers. $\mathrm{C}_{2}$ (4.00) and $\mathrm{C}_{3}$ (3.00) recorded significantly higher vaccination score over $\mathrm{C}_{3}(0.05), \mathrm{C}_{4}$ (0.06) and $\mathrm{C}_{5}$ (0.07). However, difference between $\mathrm{C}_{3}$ and $\mathrm{C}_{4}, \mathrm{C}_{4}$ and $\mathrm{C}_{5}, \mathrm{C}_{3}$ and $\mathrm{C}_{5}$ was no significant. Among districts Gautambudhnagar (1.64) recorded maximum vaccination value which was significantly higher over Meerut (1.17). Other districts were at par with the each other. It was recorded maximum for $\mathrm{C}_{2}$ category (3.69) of farmers which was significantly higher over the other farmer categories. Among districts, Bulandsahar (1.50) recorded maximum and statistically higher shelter management grad for cattle over Meerut (1.17). Difference of shelter management grad in Hapur (1.46) and Gautambudhnagar (1.40) was also 
significantly difference over Meerut (Table 4). In buffaloes viral diseases score was significantly $(\mathrm{P}<0.05) \quad$ difference among farmer categories. The score was maximum and significantly higher in $\mathrm{C}_{5}(0.10)$ over $\mathrm{C}_{1}$ (0.04). $\mathrm{C}_{3}(0.08)$ and $\mathrm{C}_{4}(0.09)$ also recorded statistically higher viral disease score over $\mathrm{C}_{1}$. Meerut and Hapur recorded maximum (both 0.09) while Hapur recorded minimum (0.06) viral disease score.

Farmer categories were significantly $(\mathrm{P}<0.05)$ difference for bacterial diseases in buffaloes. C5 recorded maximum (0.10) and significantly higher score of bacterial diseases over other farmer categories. Districts were no significantly differing from each other. Bulandsahar and Gautambudhnagar recorded higher (both 0.07) score of bacterial diseases than Meerut and Hapur (both 0.06).Fungal diseases significantly difference in buffaloes of farmer categories. $\mathrm{C}_{5}$ (0.11) showed significantly higher value of fungal diseases than $\mathrm{C}_{1}(0.05)$ and $\mathrm{C}_{2}(0.07) . \mathrm{C}_{1}$ recorded minimum incidence score of fungal diseases in buffaloes. Among districts Bulandsahar $(0.10)$ showed maximum and significantly higher fungal diseases value over Gautambudhnagar (0.06) (Table 5).
In cattle, viral diseases score was significantly $(\mathrm{P}<0.05)$ difference among farmer categories. The score was maximum and significantly higher in all the farmer categories i.e. $\mathrm{C}_{2}, \mathrm{C}_{3}$, $\mathrm{C}_{4}$ and $\mathrm{C}_{5}$ over $\mathrm{C}_{1}(0.03)$. Districts were no significantly differing from each other. Bulandsahar and Gautambudhnagar recorded higher (both 0.07) score of bacterial diseases than Meerut and Hapur (both 0.06).Farmer categories were significant differ for bacterial diseases in cattle. C5 recorded maximum $(0.10)$ and significantly higher score of bacterial diseases over other farmer categories. Districts were no significant differ from each other. Gautambudhnagar (0.07) and Hapur (0.06) recorded higher score of bacterial diseases than Meerut and Hapur (both 0.06).Fungal diseases significant difference in cattle of the farmer categories and $\mathrm{C}_{4}(0.12)$ showed significantly higher value of fungal diseases than all other categories. $\mathrm{C}_{1}$ recorded minimum incidence score of fungal diseases in cattle also. Among districts Gautambudhnagar (0.12) showed maximum and significantly higher fungal diseases value over Meerut (0.07), Hapur (0.08) and Bualandsahar (0.07) (Table 6).

Table.1 Milk Production and Milk disposal (litter/day/family) in Different categories of farmers in four districts

\begin{tabular}{llllll}
\hline $\begin{array}{l}\text { Parameters } \\
\text { Categories }\end{array}$ & \multicolumn{2}{l}{ Milk Production } & \multicolumn{2}{c}{ Milk Disposal } \\
Cattle & Buffalo & Over all & Consumed & Sold \\
\hline $\mathrm{C}_{1}$ & 1.70 & 2.65 & 4.35 & 1.85 & 2.50 \\
$\mathrm{C}_{2}$ & 2.25 & 4.95 & 7.20 & 4.10 & 3.10 \\
$\mathrm{C}_{3}$ & 3.00 & 6.80 & 9.80 & 6.00 & 3.80 \\
$\mathrm{C}_{4}$ & 4.40 & 7.30 & 11.70 & 5.90 & 5.80 \\
$\mathrm{C}_{5}$ & 5.00 & 9.05 & 14.05 & 7.30 & 6.75 \\
\hline Mean & $\mathbf{3 . 2 7}$ & $\mathbf{6 . 1 5}$ & $\mathbf{9 . 4 2}$ & $\mathbf{5 . 0 3}$ & $\mathbf{4 . 3 9}$ \\
\hline Districts & & & & & \\
Meerut & 3.20 & 5.91 & 9.38 & 4.95 & 4.25 \\
Hapur & 3.07 & 6.17 & 9.40 & 5.05 & 4.40 \\
Bulandshahar & 3.31 & 6.31 & 9.39 & 5.05 & 4.44 \\
Gautambudhnagar & 3.50 & 6.21 & 9.52 & 5.06 & 4.48 \\
\hline CD: Category & $\mathbf{0 . 1 7}$ & $\mathbf{0 . 4 2}$ & $\mathbf{0 . 2 4}$ & $\mathbf{0 . 2 3}$ & $\mathbf{0 . 2 8}$ \\
District & $\mathbf{0 . 1 5}$ & $\mathbf{0 . 3 8}$ & $\mathbf{0 . 2 1}$ & $\mathbf{0 . 2 0}$ & $\mathbf{0 . 2 5}$ \\
\hline
\end{tabular}


Table.2 Animal health grade and animal feed grade in Different categories of farmers in four districts

\begin{tabular}{lcc}
\hline $\begin{array}{l}\text { Parameters } \\
\text { Categories }\end{array}$ & $\begin{array}{c}\text { Animal Health } \\
\text { Grade }\end{array}$ & $\begin{array}{c}\text { Animal feed } \\
\text { Grade }\end{array}$ \\
\hline $\mathrm{C}_{1}$ & 4.06 & 1.50 \\
$\mathrm{C}_{2}$ & 3.06 & 2.13 \\
$\mathrm{C}_{3}$ & 3.50 & 2.56 \\
$\mathrm{C}_{4}$ & 3.44 & 3.00 \\
$\mathrm{C}_{5}$ & 4.56 & 4.13 \\
\hline Mean & $\mathbf{3 . 7 2}$ & $\mathbf{2 . 6 6}$ \\
\hline Districts & & \\
Meerut & 3.79 & 2.26 \\
Hapur & 3.40 & 2.53 \\
Bulandshahar & 3.71 & 2.75 \\
Gautambudhnagar & 3.99 & 3.12 \\
\hline CD: Category & $\mathbf{0 . 5 0}$ & $\mathbf{0 3 9}$ \\
District & $\mathbf{0 . 4 5}$ & $\mathbf{0 . 3 5}$ \\
\hline
\end{tabular}

Table.3 Details of number of Buffalo artificial insemination, vaccination and shelter Management grade in different categories of farmers in four districts

\begin{tabular}{lccc}
\hline $\begin{array}{l}\text { Parameters } \\
\text { Categories }\end{array}$ & $\begin{array}{c}\text { Artificial } \\
\text { insemination }\end{array}$ & Vaccination & $\begin{array}{c}\text { Shelter management } \\
\text { Grad }\end{array}$ \\
\hline $\mathrm{C}_{1}$ & 0.10 & 0.05 & 3.00 \\
$\mathrm{C}_{2}$ & 0.23 & 0.07 & 0.10 \\
$\mathrm{C}_{3}$ & 0.41 & 0.08 & 0.06 \\
$\mathrm{C}_{4}$ & 0.42 & 0.09 & 0.11 \\
$\mathrm{C}_{5}$ & 0.53 & 0.11 & 0.07 \\
\hline Mean & $\mathbf{0 . 3 4}$ & $\mathbf{0 . 0 8}$ & $\mathbf{0 . 6 7}$ \\
\hline Districts & & & \\
Meerut & 0.32 & 0.09 & 0.52 \\
Hapur & 0.26 & 0.07 & 0.67 \\
Bulandshahar & 0.35 & 0.10 & 0.73 \\
Gautambudhnagar & 0.42 & 0.06 & 0.76 \\
\hline CD: Category & $\mathbf{0 . 1 1}$ & $\mathbf{0 . 0 3 6}$ & $\mathbf{0 . 1 4}$ \\
District & $\mathbf{0 . 1 0}$ & $\mathbf{0 . 0 3 2}$ & $\mathbf{0 . 1 2}$ \\
\hline
\end{tabular}

Table.4 Details of number of Cattle artificial insemination and vaccination of shelter Management grade in different categories of farmers in four districts

\begin{tabular}{lccc}
\hline $\begin{array}{l}\text { Parameters } \\
\text { Categories }\end{array}$ & Artificial insemination & Vaccination & $\begin{array}{c}\text { Shelter management } \\
\text { Grad }\end{array}$ \\
\hline $\mathbf{C}_{\mathbf{1}}$ & 0.07 & 3.00 & 3.00 \\
$\mathbf{C}_{\mathbf{2}}$ & 0.11 & 4.00 & 3.69 \\
$\mathbf{C}_{\mathbf{3}}$ & 0.26 & 0.05 & 0.07 \\
$\mathbf{C}_{\mathbf{4}}$ & 0.33 & 0.06 & 0.07 \\
$\mathbf{C}_{\mathbf{5}}$ & 0.39 & 0.07 & 0.08 \\
\hline Mean & $\mathbf{0 . 2 3}$ & $\mathbf{1 . 4 4}$ & $\mathbf{1 . 3 8}$ \\
\hline Districts & & & \\
Meerut & 0.20 & 1.17 & 1.17 \\
Hapur & 0.20 & 1.50 & 1.46 \\
Bulandshahar & 0.24 & 1.40 & 1.50 \\
Gautambudhnagar & 0.29 & 1.64 & 1.40 \\
\hline CD: Category & $\mathbf{0 . 1 0}$ & $\mathbf{0 . 2 3}$ & $\mathbf{0 . 3 1}$ \\
District & $\mathbf{0 . 0 9}$ & $\mathbf{0 . 2 1}$ & $\mathbf{0 . 2 8}$ \\
\hline
\end{tabular}


Table.5 Details of number of Buffalo and Viral Disease, Bacterial Diseases and Fungal Diseases in different categories of farmers in four districts

\begin{tabular}{|c|c|c|c|}
\hline $\begin{array}{l}\text { Parameters } \\
\text { Categories }\end{array}$ & Disease & Bacterial Diseases & Fungal Diseases \\
\hline $\mathrm{C}_{1}$ & 0.04 & 0.04 & 0.05 \\
\hline $\mathrm{C}_{2}$ & 0.07 & 0.05 & 0.07 \\
\hline $\mathrm{C}_{3}$ & 0.08 & 0.06 & 0.08 \\
\hline $\mathrm{C}_{4}$ & 0.09 & 0.07 & 0.09 \\
\hline $\mathrm{C}_{5}$ & 0.10 & 0.10 & 0.11 \\
\hline Mean & 0.08 & 0.06 & 0.08 \\
\hline \multicolumn{4}{|l|}{ Districts } \\
\hline Meerut & 0.09 & 0.06 & 0.09 \\
\hline Hapur & 0.06 & 0.06 & 0.07 \\
\hline Bulandshahar & 0.09 & 0.07 & 0.10 \\
\hline Gautambudh Nagar & 0.07 & 0.07 & 0.06 \\
\hline CD: Category & 0.033 & 0.024 & 0.036 \\
\hline District & 0.029 & 0.021 & 0.032 \\
\hline
\end{tabular}

Table.6 Details of number of Cattles and Viral Diseases, Bacterial Diseases and Fungal Diseases in different categories of farmers in four districts

\begin{tabular}{lccc}
\hline $\begin{array}{l}\text { Parameters } \\
\text { Categories }\end{array}$ & Viral Diseases & Bacterial Diseases & Fungal Diseases \\
\hline $\mathbf{C}_{\mathbf{1}}$ & 0.08 & 0.03 & 0.04 \\
$\mathbf{C}_{\mathbf{2}}$ & 0.04 & 0.04 & 0.05 \\
$\mathbf{C}_{\mathbf{3}}$ & 0.07 & 0.06 & 0.11 \\
$\mathbf{C}_{\mathbf{4}}$ & 0.08 & 0.07 & 0.12 \\
$\mathbf{C}_{\mathbf{5}}$ & 0.09 & 0.08 & 0.10 \\
\hline Mean & $\mathbf{0 . 0 6}$ & $\mathbf{0 . 0 6}$ & $\mathbf{0 . 0 9}$ \\
\hline Districts & & & \\
Meerut & 0.06 & 0.06 & 0.07 \\
Hapur & 0.07 & 0.05 & 0.08 \\
Bulandshahar & 0.06 & 0.05 & 0.07 \\
Gautambudh Nagar & 0.08 & 0.06 & 0.12 \\
\hline CD: Category & $\mathbf{0 . 0 2 8}$ & $\mathbf{0 . 0 1 9}$ & $\mathbf{0 . 0 2 3}$ \\
District & $\mathbf{0 . 0 2 5}$ & $\mathbf{0 . 0 1 2}$ & $\mathbf{0 . 0 2 1}$ \\
\hline
\end{tabular}

Table.7 Details of number of Buffaloes and Artificial Insemination Breeding and Natural Breeding (units/family) in different categories of farmers in four districts

\begin{tabular}{llll}
\hline $\begin{array}{l}\text { Parameters } \\
\text { Categories }\end{array}$ & Artificial Insemination Breeding & Natural Breeding & Total \\
\hline $\mathbf{C}_{\mathbf{1}}$ & 0.40 & 0.90 & 1.30 \\
$\mathbf{C}_{\mathbf{2}}$ & 0.55 & 1.10 & 1.65 \\
$\mathbf{C}_{\mathbf{3}}$ & 0.90 & 1.80 & 2.70 \\
$\mathbf{C}_{\mathbf{4}}$ & 0.96 & 2.80 & 3.76 \\
$\mathbf{C}_{\mathbf{5}}$ & 0.80 & 1.20 & 2.00 \\
\hline Mean & $\mathbf{0 . 7 2}$ & $\mathbf{1 . 5 6}$ & $\mathbf{2 . 2 8}$ \\
\hline Districts & & & \\
Meerut & 0.52 & 1.45 & 1.97 \\
Hapur & 0.61 & 1.60 & 2.21 \\
Bulandshahar & 0.71 & 1.60 & 2.31 \\
Gautambudhnagar & 1.05 & 1.59 & 2.64 \\
\hline CD: Category & $\mathbf{0 . 1 4}$ & $\mathbf{0 . 3 1}$ & $\mathbf{0 . 4 5}$ \\
District & $\mathbf{0 . 1 3}$ & $\mathbf{0 . 2 8}$ & $\mathbf{0 . 4 1}$ \\
\hline
\end{tabular}


Table.8 Details of number of Cattles and Artificial Insemination Breeding and Natural Breeding (unit/family) in different categories of farmers in four districts

\begin{tabular}{|c|c|c|c|c|}
\hline $\begin{array}{l}\text { Parameters } \\
\text { Categories }\end{array}$ & $\begin{array}{l}\text { Artificial } \\
\text { Breeding }\end{array}$ & Insemination & $\begin{array}{l}\text { Natural } \\
\text { Breeding }\end{array}$ & Total \\
\hline $\mathrm{C}_{1}$ & 0.30 & & 0.56 & 0.86 \\
\hline $\mathrm{C}_{2}$ & 0.47 & & 0.95 & 1.42 \\
\hline $\mathrm{C}_{3}$ & 0.69 & & 1.00 & 1.69 \\
\hline $\mathrm{C}_{4}$ & 0.72 & & 1.50 & 2.22 \\
\hline $\mathrm{C}_{5}$ & 0.60 & & 1.14 & 1.74 \\
\hline Mean & 0.56 & & 1.03 & 1.59 \\
\hline \multicolumn{5}{|l|}{ Districts } \\
\hline Meerut & 0.52 & & 0.71 & 1.23 \\
\hline Hapur & 0.46 & & 0.83 & 1.29 \\
\hline Bulandshahar & 0.61 & & 1.22 & 1.83 \\
\hline Gautambudh Nagar & 0.63 & & 1.36 & 1.99 \\
\hline CD: Category & 0.69 & & 0.23 & 092 \\
\hline District & 0.62 & & 0.20 & 0.82 \\
\hline
\end{tabular}

There were significant $(\mathrm{P}<0.05)$ deference was observed in average Artificial insemination breeding among the district as well as in different categories of the farmers. $\mathrm{C}_{4}$ recorded maximum (0.96 unit/family) and statistically higher score over the other farmer categories. Gautambudhnagar recorded maximum (1.05 unit/family) score for artificial insemination followed by Bualandsahar (0.71). Natural breeding significant difference among categories of the farmer and $\mathrm{C}_{4}$ recorded maximum (2.80 unit/family) and significant higher natural breeding score than the other categories. It was no significantly difference among districts. Hapur and Bulandsahar recorded higher (both 1.60 unit/family) score than Meerut (1.45 unit/family) and Gautambudhnagar (1.59 unit/family).Overall breeding significantly differ among categories of the farmer. $\mathrm{C}_{4}$ (3.76) recorded maximum and significant higher breeding score in buffaloes over other famer categories. It was no significantly differ among districts. Among districts, Gautambudhnagar recorded maximum (2.64) breeding score which was significant higher than Meerut (1.97) and
Hapur (2.21) (Table 7). Score of artificial insemination was no significant $(\mathrm{P}<0.05)$ differ among farmer categories. However, it was higher in $\mathrm{C}_{4}$ followed by $\mathrm{C}_{3}(0.69$ unit/family). Among district also there was no significant difference regarding artificial insemination in cattle. Gautambudhnagar recorded maximum (0.63 unit/family) score of artificial insemination followed by Bualandsahar (0.61 unit/family).Natural breeding significant difference among of the farmer categories and $\mathrm{C} 4$ recorded maximum (1.50) and significantly higher natural breeding score than other categories.

It was also significant differ among districts. Gautambudhnagar (1.36) and Bulandsahar (1.22) recorded significantly higher natural breeding value over Meerut (0.71) and Hapur (0.83). Overall breeding significant difference among the farmer categories and $\mathrm{C}_{4}$ (2.22) recorded maximum and significantly higher breeding score in cattle over other famer categories. Among districts, Gautambudhnagar recorded maximum (1.99) breeding score which was significantly higher than Meerut (1.23), Hapur (1.29) and Bualandsahar (1.83) (Table 8). 
The cattle milk production was significantly $(\mathrm{P}<0.05)$ higher in $\mathrm{C}_{5}$ category $(5.00$ litter/day/family). The trend was similar in case of buffalo milk production under $\mathrm{C}_{5}$ category (9.05 litter/day/family) villages on overall basis. There were also significantly higher milk production of cattle in Gautambudhnagar district as compared to Hapur (3.07 litter/day/family) and Meerut districts. However in Bulandsahar and Gautambudhnagar districts the difference was significant. Milk production was buffalo were significantly higher in Bulandshahar district in comparison to all four districts. The study of Shukla et al., 1995; Ashalatha et al., 2004 were also reported similar observations. It was found that coefficient of Variation (CV) of milk production was low in high group as compared to medium and low groups of dairy owners. CV of milk consumption was low in low group followed by medium and high groups of dairy units. CV of milk sale was low in high group as compared to low and medium groups by Patil et al., 2010.

While studying the consumption pattern of milk and milk products in Meerut district of Uttar Pradesh observed that economic status, season, occupation, food habits and education level affect the consumption pattern significantly. As the economic status improved, the percentage share of expenditure on dairy products decreased from 22 to 18 percent. Per capita milk and milk products consumption expenditure in winter was highest rupees 280, followed by summer rupees 247 and rainy rupees 239 . It showed that family budget of graduates were at least double to that spent by illiterate families. Consumption pattern of milk products increased with increase in family budget by Singh and Kalra 2004.

It might be due to the availability of feeds \& fodder and numbers of milch animals. The milk producing cattle and buffaloes both increased with the increased in size of land holding in all the category of farmers. This might be due to an increase in proportion of lactating animals. A similar increase in mean milk production was reported by Kaur and Gill 1989.

They observed that daily milk production increased from 8.8 litters on small farms to 16.43 litters on medium and 31.50 litter on large farms in Ludhiana districts. Daily milk yield of cow and buffalo were reported 3.0 and 4.0 litter/day by Singh, R. B. and Krishna, P. V. 1975 in Meerut division of UP. In general western region of UP farmers did not allow mineral mixture feeding to the animals.

Animals were offered only wheat bran, rice, police, MOC and crushed wheat as concentrate, Chaffed fodder was fed with mixing of concentrate in this region. It was observed that heifers and other adult animals conscious lose. It may be due to lack of minerals.

Grewal and Rangi 1980 reported average milk yields of 3.0 and $4.22 \mathrm{~kg} / \mathrm{cow}$ and buffalo, respectively in Punjab. Singh 1980 reported daily milk yield of 4.05 litter for Murrah buffalo and 2.8 litter crossbred cow. The yield from local cows and buffalo were 1.8 and 3.1litter, respectively in Jaunpur district of UP. The daily milk yield in key village and non-key village areas around Karnal were reported as 2.34 and $2.37 \mathrm{~kg}$ for cows and 4.03 and $3.72 \mathrm{~kg}$ for buffalo Agarwal and Sharma, 1986. Bahadur 1988 reported daily milk of $3.6 \mathrm{~kg}$ in buffaloes in Hamirpur district of UP.

\section{Acknowledgments}

The authors are highly thankful Director of Research, S.V.P. University of Agriculture and Technology, Meerut for providing necessary facilities and funds for present research work. 


\section{References}

Aggarwal, S. B., and Sharma, K. N. (1986). Dairy management practices of Bovines in key village and non-key village area around Karnal. Indian Journal of Dairy Science. 39(1): 113-115.

Bahadur, B. 1988.Population dynamics and productive behavioural pattern of different livestock species in Hamirpur district of Bundelkhand region U.P. Thesis, M.Sc. (Animal Breeding), G.B. Pant University of Agriculture and Technology, Pantnagar, India.

Grewal, S. S., and Rangi, P. S. 1980.Economic and employment of diary in Punjab. Indian Journal of agriculture Economic, 35: 120-125.

Kaur, M. and Gill, G. S. 1989.Milk production, consumption and disposal pattern in the rural area of Ludhiana district, Punjab. Indian J. of Dairy Science, 42: 689-693.

Singh, D. K. 1980. An economioc analysis of milk production by different breeds of milch cattle on various sizes of farms in Jaunpur District of east Uttar Pradesh. Indian Journal of Agriculture Economic, 35: 158.

Singh, R. B., and Krishna, P. V. 1975. Economic of dairy farm (A comparative study of three private dairy farm in Uttar Pradesh). Indian Journal of Agriculture Economic, 30: 154.

BAHS 2012.18th Live Stock Census, Department of Animal Husbandry, Dairying and Fisheries, Ministry of
Agriculture available on http://dahd.nic.in.(Retrieval date11/01/2013).

Brithal, P. S., and Taneja, V. K. 2006. Promoting growth in Livestock Sector for Poverty Alleviation. NCAP Annual Report.2005-06.

Ashalatha, P., Rao, K. S., Reddy, P.V.S., and Moorty, P.R.S. 2004. "Impact of dairy cooperatives on the milk production, consumption and marketed surplus pattern on the members" Indian Journal of Dairy Science. 57(1): 60-64.

Shukla, D.S., Dass, B., Singh, B., and Yadav, S.R.1995. "Impact of operation flood programme on the economy of rural milk producers in Kanpur district Dehat (UP)" Indian Journal of Agricultural Economics. 50(3): 371372.

Bouler, J. M., Trecant, M., Delecrin, J., Royer, J., Passuti, N., and Daculsi, G. 1996.Macroporous biphasic calcium phosphate ceramics: Influence of five synthesis parameters on compressive strength. J. Biomed Mater Res. 32:603609

Patil, S.S., Bhavani, K., and Hiremath, G.K. 2010.Pattern of milk production, consumption and sale in different dairy units of north Karnataka. Karnataka J. Agri. Sci., 23(2): 374-375.

Singh, H.L., and Kalra, K.K. 2004.Consumption pattern of milk and milk products in Meerut District of Uttar Pradesh. Indian Journ. Of Dairy Science.57 (1): 35-42.

\section{How to cite this article:}

Satyaveer Singh, Nazim Ali, Jagdeep Kumar, Hitesh Singh and Harendra Singh Chauhan. 2017. Studies on Milk Production and Health Management for Livestock in Western Uttar Pradesh. Int.J.Curr.Microbiol.App.Sci. 6(7): 2696-2704. doi: https://doi.org/10.20546/ijcmas.2017.607.379 